\title{
РАЗРАБОТКА И АПРОБАЦИЯ ПСИХОТЕРАПИИ И ПСИХОДИАГНОСТИКИ С ИСПОЛЬЗОВАНИЕМ КОРОТКОМЕТРАЖНОГО КИНО
}

Аннотация. Объектом исследования являются короткометражные художественные/документальные фильмы и применение киноязыка / образности в психодиагностике и в психотерапии. Предметом исследования служит алгоритм психодиагностики / коррекции эмоциональных психотравм, связанных с социальной стигматизацией в силу болезни, возраста, переживаний интимно-личных взаимоотношений, зависимого и суицидального поведения с помощью авторского короткометражного кино; личный образный ряд пациента и его трансформация методами киноискусства для реализации метода терапии творческим самовыражением; визуально наблюдаемые реакции пациентов / зрителей на просмотр авторского кино и их утилизация в процессе психотерапии; закономерности психофизиологических реакций (динамика микроциркуляции) при фоновой записи во время просмотра. Методы исследования: терапия творческим самовыражением, арт-терапия, фоновая запись лазерной допплеровской флоуметрии при просмотре кино, компьютерная психодиагностика.Алгоритм исследования: 1) съемка и монтаж видеофильмов с активным включением в работу пациента (фильм о проблеме пациента и о ее разрешении); 2) демонстрация видеофильмов респондентам, не участвовавшим в киномонтаже,3) анализ особенностей восприятия при просмотре и содержания рефлексии о фильме зрителей по окончании просмотра, 4) запись ЛДФ-граммы при предъявлении авторских видеофильмов и анализ динамики бессознательной регуляции микрососудистого русла в ответ на предъявление,5) проведение компьютерной психодиагностики респондента-зрителя,6) анализ эффективности использования короткометражного авторского кино с целью психотерапии и психодиагностики.Разработан дизайн исследования, включающий 1) индивидуальную психокоррекционную терапию с пациентом для установления аутентичности, поиска значимых психоэмоциональных травм и устранения их последствий, ведущих к дезадаптации. Терапия может проводиться для постстрессовых расстройств, последствий сильной психической травмы (приковывающая к постели, лишающая трудоспособности болезнь; попытки суицида; аборт; проблемы гендерных отношений - разрыв отношений), аддикций (наркомания, курение, алкоголизм), в случае депрессивных состояний (слом смысложизненных ориентаций, сложности в определении личностной идентичности, суицидальные мысли, намерения); выявляется образный ряд, типичный для пациента; 2) создание фильма для пациента: используется психотерапевтический прием катарсиса, являющегося подобием контролируемого неврозом в миниатюре (сиибка возбуждения и торможения в ЦНС, условных рефлексов) и дальнейшей десенсибилизации к значимому стимулу и дезактуализации его; в процессе создания фильма с режиссером-психотерапевтом, продумывания сценария, реализации замысла респондент переживает ощущение собственной сопричастности, значимости его личного опыта, включения индивидуальной жизни в более широкий контекст (личностные переживания приобретают общезначимый философский контекст); 3) завершенные фильмы по окончании психотерапии являются материалом для диагностики сходных психоэмоциональных проблем, патологических реакций, представлений новых пациентов. В момент просмотра анализируются показатели: а) невербалика (поза и смены поз, жестикуляция, мимика, вегетативные реакции), вербальная реакция на эпизоды во время просмотра; б)) последующее вербальное устное и письменное отреагирование - анализ речевых проявлений (строение и расположение текста, пунктуация, семантика языковых единиц) и целеустановок; отмеченные детали, соскальзывания на актуальную для реципиента тематику эпизодов; алекситимия (отсутствие адекватных средств выражения эмоций, состояний), сокрытие переживаний; в) реакции микрососудистого русла. Протестирована возможность выявления физиологических соответствий катарсиса, скрытых мотиваций, потребностей и психоэмоциональных травм при просмотре видеофильмов (выявление суицидального риска, зависимостей, актуальности гендерных отношений и т.п.).По реакциям во время просмотра, специфике вербального отреагирования содержания фильма пост-фрактум, 


\section{Психотехника}

по количеству реактивных изменений микроциркуляции во время просмотра можно судить о степени психоэмоциональной травматизации, о предрасположенности к девиантному поведению или к психосоматизации переживаний.Зафиксированы различия в реакции во время просмотра фильмов и записи флоуметрии, связанные с культурным уровнем, возрастом, полом, актуальными потребностями. Сюжетная визуальная стимуляция (кино) в отличие от разрозненной (фотографии), обладает более мощным воздействием на состояние микроциркуляторного русла (Кv < 10), в случае удержания световода рукой испытуемого значительный тремор (Кv < 20).Фильмы, снятые при психокоррекции пациентов, вызывают резонанс у испытуемых-студентов, пережившим подобные психоэмоциональные травмы или склонных к аналогичным поведенческим патологиям (переживших их последствия). С помощью предлагаемой методики могут быть определены случаи не выявляемой в массовом прядке иными способами в социуме потребности и имеющегося опыта химических зависимостей, патологических гендерных отношений, предрасположенность к суициду. Методика может быть использована в детекции лжи. Предъявление видеофильмов дает возможность зарегистрировать активизацию нейрогенных - симпатических, эндотелиальных, миогенных факторов регуляции сосудистого русла.

Ключевые слова: стрессоры, бессознательное, память, короткометражное кино, психодиагностика, психотерапия творческим самовыражением, арт-терапия, лазерная допплеровская фрлоуметрия, психотравма, отклоняющееся поведение.

Abstract. The object of the research is a short fiction/documentary films and use of cinematic language / imagery in psychodiagnostics and psychotherapy. The subject of the research is the algorithm of diagnostics and correction of emotional psychological trauma associated with social stigma due to illnesses, age, experiences of intimate relationships, addiction and suicidal behaviour with the help of short author cinema; the personal imagery of the patient and its transformation by methods of the art implementation of the method of therapy by creative self-expression; visually observed reactions of the patients / viewers to the viewing of films and their use during psychotherapy; the regularities of psycho-physiological reactions (dynamics of microcirculation) with the help of background recording at the viewing. Research methods: creative expression therapy, art therapy, background recording laser Doppler flowmetry during screenings, computer psychodiagnostics.The algorithm of this study: 1) shooting and editing video with the active inclusion of the patient (film about the patient's problem and its resolution); 2) screening for the respondents which have not participated in film editing,3) the analysis of the perception's features at the viewing and content reflection of the audience following the screening 4) recording of LDF-grams in the presentation of the author's videos and analysis of the dynamics of unconscious regulation of the microvascular bed in response to the presentation,5) conduct computer diagnostics of the Respondent-viewers,6) analysis of the efficiency of short author cinema with the aim of psychotherapy and psycho-diagnostics. When designing the visuals features considered necessary are:1) accurate targeted registration of the most probable and possible associative Parallels of the patient - cultural, national, generational, professional, personal (used semiotic ontopsychological approaches); 2) on the other hand, the creation of freedom in interpretative activities. Following techniques have been developed and used during shooting and editing: receiving emotional contrast shots; the contrast of moving and stationary image (on photo that reflects the physiological response - closed eyes (or the symbolism of the end of life's journey as part of the movie) "black screen»); guided light hypnotic state through overloading the same type of information (repeated frames, musical fragments or phrases in the case of participation of actors); the effect of "kōan» (no unidirectional interpretation), etc. Specially developed techniques of the patient's perspective inclusion in the frame were used. One rule developed and used: the Respondent must be given the widest possible background for associations (the image is extremely generalized, lacunar). Along with the representation in the film of the specific situation in terms of deactualization process of traumatic stimuli and correction of the condition, the films have a deep philosophical implication. Lacunar technique of associative film editing is applied - special location shots and stories: adjacent slices and frames may not be thematically appositional (NLP-analogue reception in building stories) with the purpose of creating supportive spaces for individual associative.ConclusionsPossibility of identifying of physiological correspondences of catharsis, hidden motivations, needs and emotional trauma when viewing movies was tested (identification of suicide risk, dependencies, relevance of gender relations, etc.). Reactions during screenings, specifics of the verbal response to the films content after the viewing, the number of reactive changes of the microcirculation during playback allow to judge of the degree of emotional trauma, a predisposition to deviant behaviour or to psychosomatical experiences. Differences in responses while watching films and writing flowmetry associated with cultural level, age, gender, current needs are recorded. Story visual stimulation (movies) in contrast to the fragmented (photos) one, has a more powerful impact on the state of the microvasculature $(K v<10)$, in case of retention of the optical waveguide arm of the test a significant tremor $(K v<20)$. The films shot with psychotherapy patients, draw response of the subjects - students 


\section{Психология и психотехника 4(91) • 2016}

that experienced similar emotional trauma or which are prone to the same behavioral pathologies (experienced their aftereffects). Using the proposed methodology one can identify the needs of the socium typically not detected in the mass scale and using other methods and available experience of chemical dependency, pathological gender relations, a predisposition to suicide. The technique can be used in lie detection. Screenings may offer the opportunity to register the activation of neurogenic - the sympathetic, endothelial, and myogenic factors in regulation of the vasculature.

Key words: deviant behavior, psychological trauma, art therapy, laser Doppler flowmetry, psychotherapy creative expression, psychodiagnostics, short film, memory, unconscious, stressors.

Памяти А.А.Сергеева

A ктуальность исследования и степень разработанности проблемы. В современной науке рассматривается значение образа для описания индивидуальной картины мира респондента, в том числе для описания специфических ее особенностей и возможных патологий. Традиционны описания языковой картины мира в лингвистике [1-7]. Существуют словари образов и образных парадигм [8 др.]. Обнаружение через прочтение и интерпретацию образа дезадаптивных поведенческих проявлений является центральным методом некоторых перспективных направлений психотерапии [9-19]. Перечень индивидуальных смыслов, присутствующих в сознании респондента, - путь описания моделей мира в семиотике [20-22], психосемантике [23], изучении социального бессознательного [24]. Центральную роль играет установка [25] предшествующий жизненный опыт респондента с его эмоциональной окраской. Фиксация бессознательных реакций на значимые образы аппаратными методами (например, сопряженная моторная методика А. Р. Лурии [26 и др.], детекции лжи и др.) раскрывает связи между стимулами, образованные в результате спонтанного опыта на бессознательном уровне [27].

По концепции А. Менегетти [28-30], использовавшего теорию образа для анализа кино, реципиент видит мир через сложившийся под влиянием ситуаций жизни, сильных испытанных эмоций «монитор отклонения». В киноискусстве наиболее явно, наряду с творческой задачей автора, отображается и его мировоззренческая модель, а также в целом симптоматика психики. В теории кино воздействие данного вида искусства связывается с одновременным предъявлением визуального и звукового ряда (звукозрительный контрапункт). Важнейшая роль кино в оздоровлении отмечалась еще в 1940 -1950-е гг. [31, 32]. По «Модели диагностики и лечения психических поведенческих расстройств» (Приказ Минздрава РФ от 06.08.1999, № 311), аудио-визуальная стимуляция считается показанной как метод психотерапии при депрессии, циклотимии, пост-стрессовых расстройствах и др. Сейчас широко используются такие психо- терапевтические подходы, как терапия творческим самовыражением [33 и др.] арт-терапия [34 и др.]. Психодиагностика и психотерапия с помощью кино [35, 36 и др.] уже занимает свое место в диссертационных исследованиях [37-40 и др.], научных работах [41-48 и др.] и практике [49-54 и др.]. Кинотерапия уже вводится в число учебных курсов высшего образования [55 и др.].

Концепция отреагирования психоэмоциональных травм в искусстве наиболее эффективно применяются школой М. Е. Бурно [56]. В психотерапии онтопсихологии [57, 58], психодраме [59], гештальт-терапии [60, 61 и др.], НЛП (М. Эриксон, Р. Бэндлер, Дж. Гриндер, Р. Дилтс и последователи [62-66]), в биографическом подходе (Р. Штайнер [67-69]идр.)приизмененииубежденийтрадиционно используется методвоздействиячерезобразныйряд: 1) принадлежащий пациенту и трансформируемый в процессе психотерапии, 2) сформированный сознанием терапевта, осведомленного об основных свойствах образных структур, с определенными целями, 3) использование уже существующего в культуре прецедента, образного ряда (предъявление произведений разных видов искусств и исследование их интерпретаций пациентами).

В эксперименте были использованы кинофильмы, подготовленные в процессе работы врачом А. А. Сергеевым (1978-2012) [70 и др.], личное обращение к творчеству у которого произошло с целью компенсации переживания болезни (псориатический артрит, фильм «Боль»).

Доктором медицинских наук А. И. Крупаткиным и кандидатом технических наук В. В. Сидоровым разработан метод лазерной допплеровской флоуметрии (ЛДФ), определяющий особенности микроциркуляции в зависимости от активных (эндотелиальный, нейрогенный, миогенный факторы) и пассивных (дыхательные сокращения, пульсовая волна) воздействий на микрокапилляры, в том числе при воздействии функциональных проб. Метод может использоваться для описания реакций микрососудистого русла на предъявление киностимула. Флоуметрия основана на эффекте поглощения лазерного излучения молекулами ге- 
моглобина в эритроцитах. Доставка излучения к ткани и прием отраженного сигнала осуществляется с помощью световодного зонда из трех волокон: одно - для передачи зондирующего излучения, два - для приема отраженного излучения для фотометрирования. Сигнал регистрируется в течение всего времени исследования, создается графическая запись изменений перфузии (ЛДФ-грамма) [71, с.3-4]. На приводимых «скринах» графически отображена перфузия в микроциркулярах за время исследования, что позволяет сделать выводы об особенностях базального кровотока и оценить одномоментные реакции микроциркуляции. Один из показателей, выявляемых по записи, - постоянная составляющая перфузии М, характеризующая среднюю величину перфузии за временной интервал. Для исследования были значимы также «артефакты»-пикообразные отклонения от средней величины перфузии (вызванные тремором руки или изменением роли активных факторов регуляции), на демонстрируемых «скринах» экрана не удаленные. Активные факторы контроля микроциркуляции - эндотелиальный, миогенный и нейрогенный механизмы (контролируют поток крови со стороны сосудистой стенки микрокапилляра). Пассивные факторы (центральные) - пульсовая и дыхательная волна. Активные механизмы создают поперечные колебания кровотока в результате чередования сокращения и расслабления мышц сосудов. Пассивные факторы организуют продольные колебания кровотока, выражающие в периодическом изменении объема крови в сосуде. Влияние каждого из факторов (и активных, и пассивных) выделяется при анализе ЛДФ-граммы в особом разделе программы и обрабатывается отдельно. Оказалось возможным зафиксировать динамику регуляции при предъявлении кино в зависимости от значимости содержания фильма для респондента. Так, предъявление «седативных», «трансирующих» кадров увеличивает воздействие пассивных центральных механизмов регуляции (сердечный ритм, частота дыхания), воздействие стрессирующих факторов, вне зависимости от эмоционального знака, ведет к увеличению доли активных факторов регуляции. Волнообразные изображения с мелкими частыми невысокими «пиками» на ЛДФграмме - колебания нейрогенного диапазона, связанные с влияниями тех симпатических волокон, которые иннервируют соответствующие сосуды кожи. При активности эндотелия характерны колебания микроциркуляции, связанные в том числе с выбросом в кровь эндотелием микрокапилляров изменяющихся концентраций вазоактивных субстанций, в том числе оксида азота [71, с. 19].
Цель исследования: разработать технологию использования в психотерапии и психодиагностике короткометражного авторского кино; доказать возможность использования лазерной допплеровской флоуметрии (ЛДФ) для определения влияния воздействия просмотра кино на организм человека с целью определения эмоционально-значимых стимулов (ситуаций) и силы влияния аудиовизуального ряда.

\section{Задачи исследования:}

1. Разработать алгоритм создания и использования авторского короткометражного кино, имеющего психокоррекционный и психодиагностический эффекты.

2. Разработать методику обнаружения с помощью лазерного анализатора капиллярного кровотока (ЛАКК-02) бессознательных реакций на просмотр короткометражного кино с целью выявления психотравм, мотиваций личности и склонности к различным формам отклоняющегося поведения.

Объектом исследования являются короткометражные художественные/документальные фильмы и применение киноязыка / образности в психодиагностике и психотерапии. Предметом исследования являлася выработка алгоритма психодиагностической и психотерапевтической работы с помощью короткометражного кино, личный образный ряд пациента и его трансформация методами киноискусства для реализации метода терапии творческим самовыражением, визуально наблюдаемые реакции пациентов / зрителей на просмотр авторского кино, закономерности психофизиологических реакций (динамика микроциркуляции) при фоновой записи во время просмотра.

\section{Материал исследования}

1. Системы образов респондентов.

2. Авторское короткометражное (8-15 мин.) кино («Спички», «Небо», «Дым», «Ложь», «Сон», «Боль», «Летние забавы», «Часы посещения», «Бабочка» и др., дата съемки: 2003-2011 гг.).

3. Записи ЛДФ-граммы при просмотре (апрельиюнь 2011 гг.). Вербальная и невербальная реакция респондентов-зрителей на «болезненный» аудиовидеоряд.

4. Данные зрителей по компьютерному варианту опросника для определения акцентуаций К. Леонгарда (для респондентов-зрителей) из сертифицированного набора психодиагностических тестов MMPI II («PSYCOM»).

Методы исследования: терапия творческим самовыражением, арт-терапия, фоновая запись ла- 


\section{Психология и психотехника 4(91) • 2016}

зерной допплеровской флоуметрии при просмотре кино, компьютерная психодиагностика.

\section{Алгоритм исследования:}

1) съемка и монтаж видеофильмов с активным включением в работу пациента (фильм о проблеме пациента и о ее разрешении);

2) демонстрация видеофильмов респондентам, не участвовавшим в киномонтаже,

3) анализ особенностей восприятия при просмотре и содержания рефлексии о фильме зрителей по окончании просмотра,

4) запись ЛДФ-граммы при предъявлении авторских видеофильмов и анализ динамики бессознательной регуляции микрососудистого русла в ответ на предъявление,

5) проведение компьютерной психодиагностики респондентов-зрителей,

6) анализ эффективности использования короткометражного авторского кино с целью психотерапии и психодиагностики.

\section{Респонденты:}

1. Пациенты психолога, женского и мужского пола, различного возраста, на основании психотерапии которых создавались видеофильмы, как материал дезактуализации психоэмоциональных переживаний, зависимостей, девиантного поведения.

2. Респонденты женского и мужского пола (студенты медицинского вуза), являвшиеся зрителями. Тестировалась возможность по реакции на кинофильмы определить специфику психоэмоциональных травм испытуемых или их склонность к тем или иным особенностям поведения (не менее испытуемых с записью ЛДФ-граммы и сопровождающимся психологическим тестированием).

\section{Дизайн исследования (I - III этап):}

1. Проводится индивидуальная психотерапия с пациентом: для пост-стрессовых расстройств, последствий сильной психической травмы (приковывающая к постели, лишающая трудоспособности болезнь; попытки суицида; аборт; проблемы гендерных отношений / разрыв отношений), аддикций (наркомания, курение, алкоголизм), в случае депрессивных состояний (слом смысложизненных ориентаций, сложности в определении личностной идентичности, суицидальные мысли, намерения). Выявляется образный ряд, типичный для пациента.

2. Создается фильм: пациент в ходе совместного творческого процесса экстериоризует пережи- вания, контролируемо отреагирует их. Кино выполняет роль способа выведения травмы или дезадаптивного, отклоняющего представления за пределы личности (осмысление проблемы отдельно от пациента). Используется психотерапевтический прием катарсиса (столкновение противоположных чувств, свойственное восприятию сюжетных произведений драматического искусства, прежде всего трагедии), являющегося по типу реакций контролируемым неврозом в миниатюре (сшибка возбуждения и торможения в ЦНС, условных рефлексов) - способом десенсибилизации к значимому стимулу, дезактуализации переживания. В процессе создания фильма с режиссером-психотерапевтом, продумывания сценария, реализации замысла респондент переживает ощущение собственной сопричастности к творчеству, осознает значимость своего личного жизненного опыта, переживает включение собственной жизни в культурный контекст.

3. Готовые фильмы по завершении психотерапии являются материалом для диагностики сходных психоэмоциональных проблем, патологических реакций, представлений, черт личности новых пациентов.

Анализируемые при просмотре показатели (методы обнаружения конгруэнтности и значимости предъявляемого звуко-зрительного ряда):

1. Невербалика (поза и смены поз, жестикуляция, мимика, вегетативные реакции), вербальная реакция на эпизоды во время просмотра.

2. Последующее вербальное отреагирование, его тип: анализ речевых проявлений (строение, семантика текста); отмеченные детали, соскальзывания на актуальную для реципиента тематику эпизодов; алекситимия (отсутствие адекватных средств выражения эмоций, состояний); сокрытие переживаний.

3. Динамика микроциркуляции.

Невербальные реакции во время просмотра и регистрируемая с помощью ЛДФ-граммы динамика микроциркуляции, изменения показателей капиллярного кровотока указывают на ситуации, стрессирующие реципиента, фиксированные на уровне висцеральной памяти [72]. Если после просмотра респондент говорит, то при наличии должного уровня самоконтроля и укрываемых ситуаций срабатывает осознанная и неосознанная цензура. В силу психологической защиты, могут быть «забыты» значимые, но неотреагированные стимулы, вызвавшие физиологическую реакцию при просмотре, но не отраженные в вербальном пересказе фильма зрителем. 


\section{Предварительные результаты исследования} (конструирование видеофильмов)

Созданные видеофильмы могут быть классифицированы по следующим критериям:

1) фильмы со звучащим текстом - без звучащего текста (музыкальные фрагменты - преимущественно);

2) с системой персонажей (документальной съемкой или подготовленными актерами) и абстрактные фильмы без персонажей (использование широкого ассоциативного поля аллегории - неодушевленные предметы, представители флоры, фауны как персонажи; или эффект через изменение пространственновременных континуума, рамки).

При конструировании видеоряда были необходимы:

1) точный адресный учет наиболее вероятных и возможных ассоциативных параллелей пациента - общекультурных, национальных, поколенческих, профессиональных, личностных;

2) создание свободы в интерпретативной деятельности.

При подборе образного ряда кино было использовано правило: респонденту должен быть дан возможно наиболее широкий фон для ассоциаций (изображение предельно обобщенное, лакунированное). В ходе и после просмотра видеофильма пациент провоцируется на вербальное отреагирование.

Используемые при съемке и монтаже приемы: прием эмоционального контраста кадров; контраст движущегося и стационарного изображения (включение фото, черного экрана и др.); наведение гипнотического состояния (источник света, повторяющиеся кадры, музыкальные фрагменты, фразы); эффект «коана» (отсутствия однонаправленной интерпретации) и др.

Используются следующие виды включения точки зрения пациента в кадр:

1) наблюдатель,

2) наблюдение за наблюдающим,

2) идентификация с персонажем,

3) эффект присутствия в кадре (аналог интерактивной игры: «Небо»),

4) поле экрана превращается в поле зрения зрителя.

Наряду с отражением в фильме конкретной ситуации, с которой шла работа (адддикции -фильм «Когерентность», «Вангелис», «Ложь»; суицидальные намерения - «Небо»; умирание - «Сон»; болезнь - «Боль»; расставание в паре «Сказка»; нескладывающиеся гендерные отношения - «Спички»; роды или пережитый пациентом в паре травматичный аборт - «Змей»; отношение к женскому образу, формирование идентичности - «Часы посещения»; перверсии - «Бабочка» и др.), фильмы имеют глубинный философский подтекст. В их видеоряде обыгрываются психологические понятия (например, «когерентность», «ситуации витальной угрозы», «самосовершенствование», «вдохновение» и др.), архетипические образы и др.

Прием ассоциативного киномонтажа (лакунирование). При киномонтаже использован особый принцип расположения кадров и историй. Существуют линейный (кадры следуют друг за другом, характерен для С. Эйзенштейна) и дистантный (близкие по времени съемки и смыслу кадры отстоят друг от друга в потоке кино, характерен для кинодокументалиста классика короткометражного кино Артавазда Пелешяна) типы монтажа. В данном наборе видеофильмов кадры могут быть тематически не соположены: использован ассоциативный монтаж с целью создания благоприятного пространства для раскрытия индивидуального ассоциативного ряда реципиента по поводу предлагаемых историй (киноаналог теста Роршаха или приема лакунирования в техниках НЛП).

\section{Содержание фильмов, созданных в ходе работы с пациентами}

Короткометражный фильм «Дым»

Фильм монохромный. Мелькают титры фильма, набор надписей вводит мысль о разнообразном содержании жизни, воссоздается аналог молитвы в традициях исихазма (молитва молчальников) или стихотворения, с символикой подведения итогов жизни. Звучит музыкальная композиция Akira Yamaoka «Комната ангела» («Room of Angel») о материнской депревации и расставании с матерью. Действие происходит в комнате коптерки. Видны голова и плечи человека, сидящего на переднем плане в кресле-качалке спиной к зрителю. В центре помещения, но ближе в правому краю кадра виден низкий столик, на нем свеча. Человек наклоняется, зажигает свечу, закуривает сигарету, покачивается в кресле. В центре кадра - светлые лучи, исходящие от свечи, ими освещена рука - как бы парафраз горящей на черном фоне свечи. Внизу справа появляются титры. Буквы мигают, падают сверху, появляются поочередно. Первая фраза: «Благодарим за помощь». Следует утомляющее ироническое, меняющимися по цвету буквами на фоне монохромности фона перечисление объектов благодарности: сигаретная фабрика, фабрика по производству креселкачалок, ЖЭУ 15, автору музыкального фрагмента, производителю презервативов. Используется эф- 


\section{Психология и психотехника 4(91) • 2016}

фект обманутого ожидания: зритель ждет дальнейшего развития смысла. По окончании перечисления появляются красные буквы (резкие по сравнению с пастельными тонами букв перечислении) псевдоним автора. Имя выдерживается с повышенной длительностью, затем исчезает. Музыкальная композиция заканчивается. Сигарета докурена, персонаж гасит свечу. Видна его рука, светящаяся, в задумчивости поднесенная к лицу. Лицо зритель не видит на протяжении всего просмотра. Покачивание в кресле является парафразом внутриутробного пребывания. Монотонность музыки, движения и точки света на экране создает у зрителя измененное состояние сознания. Титры превращаются в благодарность за то, как случайно была дана и протекала жизнь, за то, что в ней случилось. Выкуренная сигарета выступает как мифологема краткости жизни. Образный ряд коррелирует с эстетикой андеграунда, психоделического и медитативного кино. Для наркозависимых актуализируется иная интерпретативная парадигма (их специфическая физиологическая и поведенческая реакция на фильм позволяет определить наркозависимых). Наведение транса осуществляется с помощью следующих приемов. В кадре присутствует несколько композиционных центров, рассредоточивающих внимание: 1)движущийся покачивающийся персонаж внизу экрана (слежение за актером); 2) точка горения свечи. Сосредоточение на противоположных краях экрана индуцирует человека к постоянному легкому движению мышц глаза, повороту глаз (что приводит к утомлению мышц, монотонии, совместно с чернобелым типом изображения и монотонной музыкой, точкой свечения на экране, и способствует наведению транса). Эффект усиливают присутствующие на экране две горящие точки - свеча и кончик лучащейся сигареты. По реакции на курение может быть исследовано у респондента место курения в системе ценностей и снято возникающее при просмотре возможное тяготение к зависимости: здесь взамен курения предложен эффект расслабления за счет аудиовизуального ряда. Горящая свеча и сигарета в философском аспекте могут быть прочитаны как миф о жизни и душе (горящая свеча), краткости и несущественности отдельной человеческой жизни в масштабах вечности, не превосходящей по значимости и длительности времени выкуривания сигареты / горения свечи. Образы «жизнь - выкуренная сигарета, задуваемая свеча», «пребывание в мире - качание в кресле» (парафраз перинатальных и трансовых переживаний), мотив бессмысленности жизни и благодарности-молитвы (иронический образ титров на экране) за все, кажущееся и мелким, и значительным, что было в ней, способствуют ре- ализации функции отреагирования депрессивных и субдепрессивных витальных переживаний отсутствия смысла пациентом фильма и зрителями.

Если, как и пациент фильма, его зритель также подвержен подобным размышлениям и склонен к депрессии, суициду, то образы фильма вызовут физиологическую реакцию и, возможно, вербальное отреагирование. Данный фильм, отражающий витальные переживания прошедшей жизни [73] и вводящий в измененное состояние сознание, облегчающее доступ к глубинным слоям архетипических образов [74], позволяется отреагировать личные переживания о жизни. Фильм может быть использован для диагностики аддикций (курение, наркозависимость).

\section{Короткометражный фильм «Небо»}

Фильм построен на идентификации персонажа с птицей и состоит из кадров, показывающих полет птицы в небе, а затем вверх - вглубь облаков, на меняющемся фоне (естественные тона неба, желтоватый фон, красные облака). Его озвучивают две контрастные музыкальные композиции: жизнеутверждающая в первой части фильма «The Show Must Go On» группы «Queen» и исполняемая шепотом во второй части фильма. Равномерный полет птицы в небе, наблюдаемый со стороны в первой части фильма, сменяется во второй части убыстренной съемкой движения вглубь облаков самого персонажа, идентифицированного с птицей, и фрагментами видов облаков различных цветовых оттенков. Полноцветные кадры во второй части фильма перемежаются мельканием черного фона (образ открытых - закрытых глаз). Тональность музыкального ряда во второй части фильма существенно изменяется: от жизнеутверждающей музыки Фредди Меркьюри к медленной композиции и полушепоту. В конце фильма музыка с шепчущим голосом исполнителя продолжается на фоне черного экрана.

Короткометражный фильм «Змей» Фильм состоит из четырех фрагментов.

1. Над накрытым цветной, почти «домашней», простыней человеком суетятся врачи. У зрителя возникает представление, что вскрывают грудную клетку лежащего. Возникает мысль о том, что речь идет о трупе, вскрытии и, как следствие, отторжение, яркая эмоциональная реакция, страх. В дальнейшем оказывается, что зритель видит киносъемку родов - операцию «Кесарево сечение»: на экране появляется окровавленный младенец. Видна пуповина (образ пуповины, «нити жизни» в кинофильме является центральным). Зритель испытывает катарсис. 


\section{Психотехника}

2. Снова изображен лежащий пациент, укрытый простыней. Видна раскрытая нога. Врачебная бригада выполняет венозное шунтирование. Вшивается новая «нить жизни». Фон и сами кадры фильма отличаются пестротой.

3. Запускают бумажного змея. Показан его полет. По дороге среди поля идет человек. Фрагмент созвучен по пестроте цветового оформления с кадрами операций.

4. Коротко остриженный герой, нескладный внешне персонаж (молодой человек) рисует на листе бумаги красную черту, затем синюю, растушевывает линии плевком (его замысел непонятен зрителю). Затем рисует угол, соединяющую стороны угла линию. Изображение напоминает букву А (возникает аллюзия «Вначале было слов», «Альфа и Омега» и др.). Сгибая бумагу и прикрепляя ее к тонким веткам, персонаж завершает изготовление воздушного змея (возникает аллюзия на процесс изготовления первочеловека из глины и др.).

Фильм описывает мифологемы рождения и жизни как полета воздушного змея, рождения из небытия, сополагает рождение и исчезновение. Констатируется образ связи с Целостностью, основой, самой жизнью через нить, пуповину. Развивается образ обрезаемой, изымаемой и обновляемой «нити», образ «чистого листа» - человека, на котором мир пишет свои письмена. Фильм о сакральном - рождении и чуде спасения жизни сопровождается трансирующим тувинским горловым пением. Фильм может быть использован для предъявления респондентам, пережившим ситуацию потери ребенка (аборта), для диагностики суицидальных намерений, депрессии.

\section{Короткометражный фильм «Сказка»}

Фильм об освобождении от любовной зависимости после вынужденного разрыва брака через возрастную регрессию (уход в детские переживания) транс (верчение, кружение), уход в природу и поэзию (творчество).

Киноновелла состоит из трех частей:

1. Мужчина в возрасте около 40 лет страдальчески смотрит на вырезанный из картона профиль утраченной возлюбленной. Потом - на экран телевизора с рябью, перемежающейся кадрами эротического фильма. Взгляд многократно переводится с силуэта на экран, видна меняющаяся мимика лица героя, переживающего страдания от воспоминаний.

2. Тот же герой в холодные, но бесснежный период смотрит в кинообъектив, лицо его отражает страдания. Персонаж кружится на фоне иллю- минированных фигурок животных, и предновогодних невысоких елей в детском парке, переживая трансовое состояние, возрастную регрессию.

3. На фоне снежной долины герой фильма последовательно сбрасывает одежду, отбрасывая также предметы пытки и символы несвободы, уходит вдаль по снегу босой. Звучит стихотворение Арсения Тарковского. Смысл: очистившись от желаний, человек, отбросив эмоциональное страдание, уходит в чистоту (снежное поле), страдание рождает творчество и поэзию.

\section{Короткометражный фильм «Вангелис»}

Пациент - девушка со склонностью к асоциальному поведению, промискуитету. Фильм состоит из двух частей: первая - морские пейзажи и сюжет с полуобнаженной девушкой, звучат композиции Вангелиса; вторая - съемки церковных фресок и церковная музыка, струящаяся в ручье вода.

1. В начале фильма на фоне моря появляется лицо актера на фоне моря, слышна произносимая фраза «Я не знаю, зачем я здесь, и как я здесь оказался». Следуют фрагменты природной съемки: море, закат, струящаяся вода, мост. Девушка в маске, с кальяном в руках у украшенной рождественской ели манит к себе рукой зрителя, водя по ярко накрашенным губам. Вводится контрастный кадр - мостик в море; вода, омывающая камни. Девушка курит кальян, через красную трубку, похожую на пуповину. Девушка исчезает, растворяясь в изображении фресок.

2. На ее месте появляются съемки святых ликов из старых монастырей. Камера задерживается на образах людей, готовящихся к «Страшному суду». Завершается фильм образом камней, искрящихся на солнце, опавших листьев в струящейся воде, изображением дороги вдаль среди деревьев с осенней листвой.

Короткометражный фильм «Летние забавы» Фильм о формировании сложной системы ложных мировоззренческих построений, о множественной интерпретации обыденности.

Может быть использован для диагностики зависимостей.

Два друга на фоне высокой травы на лугу ведут разговор. Возникают культурные ассоциации со стихами И. Бродского («Холмы»), А.Твардовского («На сеновале») и в целом культурным архетипом сократического спора. Один из друзей (проводя проверку на суггестивность), пытается убедить собеседника в том, что камень на железнодорожном пути - осколок метеорита. Воплощаются в визуальном ряде метафоры путаницы человеческих мыс- 


\section{Психология и психотехника 4(91) • 2016}

лей. Например - путаницу мыслей символизирует сплетаемая из черной проволоки на белом столе фигура-паутина. Символом хаоса в сознании (мозге) становится прозрачный стеклянный чайник с насекомым - богомолом внутри. Богомол, символизирующий механической начало, агрессию, поедает шмеля (образ в культе связан с образом истины). На следующих кадрах показан складываемый кем-то на пляже из плоских камней-гальки замок (строится и уплотняется система представлений, картина мира). Показаны люди на пляже, символизирующие родство, но также искаженное или связанное с болью, страданием: мать и сын-инвалид, девочка и отец. Съемки переносятся в дом престарелых: слепой старик тщетно пытается закурить, показан умирающий пациент. В аудиоряд включены равнодушные слова санитарки с пожеланиями ему смерти. Фильм показывает, как трансформируется образ духовной и семейной близости людей и искажаются системы их представлений о мире.

\section{Короткометражный фильм «Спички»}

Фильм о взаимоотношениях в паре. Метафорически показаны 18 историй пар, «вечной пары», актуализирована тема жизни и смерти (горение, угасание, падение, возрождение) - использован принцип техники медитации на свечу, наведение транса через переутомление, слежение за двумя зонами внимания (точки горения), через однотипность мелодии и происходящего на экране. Кадр наполняют успокаивающие цвета - синий цвет фона и желтый цвет пламени, песка. На синем фоне чья-то рука зажигает две спички. Горящие пары спичек (правая ниже, чем левая, что символизирует гендерную отнесенность) символизируют типы отношений. В процессе горения спички то падают, то склоняются друг к другу, приподнимаются (символика возрождения, выхода из кризиса) и соединяются в процессе горения (символика достижения взаимопонимания, гармонии отношений). Повторяющихся историй нет. Пациенты быстро впадают в трансовое состояние, по реакции (как невербальной - многие зрители плачут, так и по реакции микроциркуляторного русла) диагностируется значимость и травматичность для пациентов межгендерных отношений. Фильм сопровождается женским хоровым католический каноном.

\section{Результаты записи фоновой лазерной допплеровской флоуметрии}

Приведем и кратко проанализируем записи ЛДФграммы при просмотре авторского короткометражного кино.
Реакция на фильм «Небо»

Рисунок $1(a, б)$. Пациентка 1. Отсутствие суицидальных тенденций. Данные опросника К. Леонгарда для определения акцентуаций: экзальтация (24), тревожность (21 балл при норме до 14-ти), застревание (20), возбудимость (18)). Реакция пациентки на фрагмент первый - «полет птицы», фрагмент второй - «полет в облака».

Рисунок 2. Пациент 6. Респондент мужского пола с выраженными суицидальными тенденциями в анамнезе. Выраженные колебания показателей МЦР (вазоконстрикция-вазодилятация, изменение кровенаполнения и скорости кровотока. Акцентуированность по шкалам: экзальтация, тревожность, циклотимия, эмотивность, возбудимость.

\section{Реакция на фильм «змей»}

Рисунок 3. Пациент 7. Отдельные пиковые реакции микрокапилляров у пациента мужского пола на кадры (роды путем «Кесарево сечение», венозное шунтирование). Увеличение кровенаполнения и случай тремора при переходе к эпизодам запускания змея (философский образ, метафолически описывающий творение человека и его связь с жизнью). Акцентуированность на шкале гипертимность.

\section{Реакция на фильм «Спички»}

Рисунок 4. Пациент 3. У пациентки проявилась отчетливая реакция МЦР на просмотр фильма. Данная тема является травматичной. Акцентуированность по шкале экзальтации.

Рисунок 5. Пациент 1. Последействие фильма и коррекция состояния - транс («Остров») после видеозаписи (с середины записи). После психотерапевтического транса - возвращение к аналогичному состоянию у пациентки. В анамнезе - давнее желание выйти замуж, отсутствие гендерных отношений.

Рисунок 6. Пациент 2. Заметны отдельные эпизоды изменений кровотока и тремора. Для студентки 1 курса оказываются минимально значимыми как тема суицида, так и гендерных отношений. Акцентуированность респондентки по шкалам: возбудимость, гипертимность, педантизм.

Рисунок 7. Пациент 5. Респондентка находится в травмирующих ее гендерных отношениях (связь с женатым партнером), что зафиксировано в реакции МЦР при просмотре фильма: ярко выраженный тремор (падение изолинии до нуля), в остальных фрагментах - повышенная реактивность показателей кровотока - изменения в МЦР в ходе просмотра. Согласно опроснику К. Леонгарда акцентуированность по шкалам: демонстративность, гипертимность. 


\section{Психотехника}

Рисунок 8. Пациент 8. Респондент мужского пола, студент 3-го курса, в академическом отпуске по неуспеваемости и переживаний опыта травматичных взаимоотношений с однокурсницей. Тремор на завершающей части фильма, описывающей «взаимопонимание» (совместное горение) в паре, недоступное для пациента.

Рисунок $9(a, 6,8)$. Пациент 7. Вид ЛДФ-граммы в целом. Амплитудно-частотный спектр. Вейвлетанализ (активные и пассивные факторы регуляции кровотока в МЦР при предъявлении кино). Тема не травматична, артефактов нет. Прослеживается предстартовое волнение. Данные об активных и пассивных факторах регуляции кровотока в МЦР: активные факторы 1) эндотелиальный, 2) нейрогенный, 3) миогенный; пассивные: 4) дыхательная волна, 5) сердечная волна.

Реакция на фильм «Вангелис»

Рисунок 10. Пациент 7. Ярко выраженный тремор у пациента мужского пола на кадры обнаженной натуры с кальяном в противовес спокойной реакции на изображения моря, текущей воды, икон, дороги. При использовании негативной стимуляции фильмы имеют корректирующий ее финал. Респондент акцентуирован по шкале гипертимность).

Реакция на фильм «летние забавы»

Рисунок 11 (a,б,в). Пациент 6. Фрагменты, отражающие стабильное состояние МЦР, пиковые изменения кровенаполнения в ответ на кадр, артефакты в виде тремора. Респондент акцентуирован по шкалам: экзальтация, тревожность, циклотимия, возбудимость, эмотивность, педантизм.

Рисунок 12. Пациент 7. Фрагменты записи, отражающие изменение кровенаполнения на кадры фильма. Акцентуированность по шкале гипертимность.

Реакция на фильм «Дым»

Рисунок 13. Пациент 1. В анамнезе у пациентки - актуальные переживания по поводу болезни брата во время службы в армии, вызванной курением. Пациентка является «личностью, склонной к травматизации» (случайные переломы конечно- стей, вывихи), на ЛДФ-грамме - тенденция к формированию «гипертонической личности».

\section{Выводы}

Протестирована возможность выявления моментов физиологического проявления катарсиса, скрытых мотиваций, потребностей и психоэмоциональных травм при просмотре видеофильмов (выявление риска суицида, зависимостей, актуальности травматичных гендерных отношений и т.п.), прежде всего с помощью фоновой записи флоуметрии микрокапилляров.

Сюжетная визуальная стимуляция (кино) в отличие от разрозненной (фотографии), обладает более мощным воздействием на состояние МЦР (Kv < $10)$, в случае удержания световода рукой испытуемого - значительный тремор $(\mathrm{Kv}<20)$.

Зафиксированы различия в реакции во время просмотра фильмов и записи ЛДФ, связанные с культурным уровнем, возрастом, полом, актуальными насущными потребностями. Так, респондентки 1, 2, 3 курса с разным опытом взаимоотношений по-разному реагируют на просмотр фильма «Спички».

Фильмы, снятые при психокоррекции пациентов, вызывают резонанс у испытуемых, переживших подобные психотравмы / склонных к аналогичным поведенческим патологиям (или переживших их последствия).

По особенностям реактивных изменений МЦР при фоновой записи флоуметрии можно судить не только о вовлекаемости и эмоциональной лабильности респондента (в том числе в сопоставлении с данными по опроснику К. Леонгарда), но и о степени психоэмоциональной травматизации и предрасположенности к девиантному поведению (если оно отображено в фильме).

Могут быть определены случаи не обнаруживаемой другими способами в социуме потребности и имеющегося опыта химических зависимостей, патологических гендерных отношений, предрасположенность к суициду. Методика может быть использована в детекции лжи.

\section{Список литературы:}

1. Апресян Ю.Д. Модель «Смысл-Текст» на современном этапе: теория и приложения // Фонетика и нефонетика. К 70-летию Сандро В. Кодзасова.-М.: «Языки славянских культур», 2008.-С. 87-103.

2. Апресян Ю.Д. От истины до лжи по пространству языка // Логический анализ языка. Между ложью и фантазией. Отв. ред. член-корреспондент РАН Н.Д. Арутюнова.-М., 2008.-С. 23-45.

3. Апресян Ю.Д., Апресян В.Ю., Бабаева Е.Э., Богуславская О.Ю., Иомдин Б.Л., Крылова Т.В., Левонтина И.Б., Санников А.В., Урысон Е.В. Языковая картина мира и системная лексикография.-М.: Школа «Языки славянских культур», 2006.-910 с.

4. Вежбицкая А. Понимание культур через посредство ключевых слов / Пер. с англ. А. Д. Шмелёва. - М.: «Языки славянской культуры», 2001. - 288 с. 


\section{Психология и психотехника 4(91) • 2016}

5. Вежбицкая А. Язык. Культура. Познание / Пер. с англ., отв. ред. М. А. Кронгауз, вступ. ст. Е. В. Падучевой. - М.: «Русские словари», 1996. - 416 с.

6. Левонтина И. Б., Шмелев А. Д., Зализняк А. А. Константы и переменные русской языковой картины мира.- М.: «Языки славянской культуры», 2012.- 696 с. (Язык. Семиотика. Культура) .

7. Урысон Е.В. Проблемы исследования языковой картины мира: Аналогия в семантике.-М.: «Языки славянской культуры», 2003. - 224 c.

8. Павлович Н. В.Язык образов: парадигмы образов в русском поэтическом языке. 2-е изд., испр. и доп. - М.: «Азбуковник», 2004. - 528 с.

9. Морено Я. Л. Социометрия: Экспериментальный метод и наука об обществе / Пер. с англ. А. Боковикова.-М.: «Академ. Проект», 2004.-315 с.

10. Перлз Ф. С. Теория гештальт-терапии = Gestalt therapy: excitement and growth in the human personality / Пер. $\mathrm{c}$ aнгл. А. Корневой, В. Петренко. - М.: Ин-т общегуманитарных исследований, 2008. - 318 с.

11. Бурно М. Е. Клинический театр-сообщество в психиатрии. - М.: «Альма Матер»; «Акад. Проект», $2009 .-718$ с.

12. Бурно М. Е. Клиническая психотерапия: Учебное пособие по психотерапии. 2-е изд., перераб. и доп. - М.: «Академический Проект»; Екатеринбург: «Деловая книга», 2006. - 719 с.

13. Лейтц Г. Психодрама: Теория и практика. Классическая психодрама Я. Л.Морено / Пер. с нем. А. М. Боковикова. Изд. 2-е, испр. и доп. - М.: «Когито-Центр» , 2007.-379 с.

14. Менегетти А. Образ и бессознательное. [Изд. 2-е.перераб. и доп. - М.: «Онтопсихология», 2009.-604 с.

15. Менегетти А. Введение в онтопсихологию. Изд. 2-е, испр. и доп. - М.: «Онтопсихология», 2006. - 127 с.

16. Менегетти А. Система и личность. Изд. 4-е, испр. и доп. - М.: Науч. фонд «Антонио Менегетти», 2015.-276 c.

17. Эриксон М. Гипнотерапия: Случаи из практики / Пер. с англ. под общ. ред. Г.Бутенко. - М.: «Психотерапия», 2013.-516 с.

18. Эриксон М. Стратегия психотерапии = Strategy of the Psychotherapy: Избранные работы / Авторизов. пер. с англ. и ред. Шлионский Л.М.-СПб.: «Речь», 2002. - 542 с.

19. Корнеенков С.С. Психодиагностика, психокоррекция и психотерапия субъективных переживаний страха в измененных состояниях сознания // Психолог. - 2013. - 4. - С. 238 - 278. DOI: 10.7256/2409-8701.2013.4.122. URL: http:// www.e-notabene.ru/psp/article_122.html

20. Лотман Ю.М. Семиотика кино и проблемы киноэстетики. - Таллин: Издательство «Ээсти Раамат», 1973. - 137 с.

21. Лотман Ю.М., Цивьян Ю.Г. Диалог с экраном.-Таллинн: «Александра», 1994.-215 с.

22. Фарыно Е. Введение в литературоведение.-М.: Издательство РГПУ им. А.И. Герцена, 2004. - 639 с.

23. Петренко В.Ф. Основы психосемантики.-2-е изд., доп. - СПб.: «Питер», 2005. - 480 с.

24. Крокинская О.К., Поссель Ю.А., Сикевич З.В. Социальное бессознательное. - СПб.: «Питер», 2005.-272 с.

25. Узнадзе Д.Н. Психология установки.-СПб.: «Питер», 2001. - 416с.

26. Лурия А. Р. Язык и сознание / Под редакцией Е. Д. Хомской. -- М: Изд-во Моск. ун-та, 1979.-320 с.

27. Костандов Э.А. Психофизиология сознания и бессознательного.-СПб., 2004. - 176 с.

28. Менегетти А. Мудрец и искусство жизни. Изд. 4-е .-М.: Науч. фонд «Антонио Менегетти», 2015.-113 с.

29. Менегетти А. Кино, театр, бессознательное. Т. 1. / Пер.с итал.: Родик М. А. и др. 2. изд., испр. и доп.-М.: «Онтопсихология», 2004. -264 с.

30. Менегетти А. Кино, театр, бессознательное. Т.2. / Пер.с итал.: Родик М. А. и др.-2. изд., испр. и доп.-М.: «Онтопсихология», 2003. -222 с.

31. Сухаребский Л. М. Военно-санитарные медицинские и физкультурные кинофильмы. 2-е изд. - М.: «Главкинопрокат», 1944.--26 с.

32. Лаврентьев В.И. Медицинский учебный фильм-возможности, сценарий, использование // Материалы Всесоюз. науч.-метод. конференции по оптимизации учеб. процесса в высш. мед. учеб. заведениях.-Каунас, 1969.-24 с.

33. Бурно М. Е. Терапия творческим самовыражением: Отечественный клинический психотерапевтический метод. Учебно-практическое пособие по психотерапии и психологическому консультированию. 4-е изд., испр. и доп. - М.: «Альма Матер»; «Академический Проект», 2012.-487 с.

34. Золотовицкий Р. А. Организационная арттерапия и тренинг = Organizational arttberapy: Социодрама и социометрия в работе с организацией.-М.: «Морено-Институт»; АРК «Бизнес Групп», 2003.-208 c.

35. Mastronardi V.M. I film che aiutano a stare meglio: Filmtherapy.-Roma: «Armando», 2010.-237 c.

36. Васютин А. М. Психоанимационная терапия, или Лечение болезней души и тела с помощью образных психотерапевтических фильмов.-Ростов-на-Дону: «Феникс», 2015. - 316 с.

37. Дудник Д.В. Ситуационно обусловленные психогенные психические расстройства у военнослужащих внутренних войск Министерства внутренних дел Российской Федерации в условиях воинской службы вне боевых действий и их лечение. Автореф... канд.мед.н. - Оренбург, 2007. - 26 с.

38. Кащук А.А. Суггестивные свойства телевидения. Автореф... канд.искусствоведения. - М., 2007. - 26 с.

39. Чикирис А.Г. Телевизионное вещание. Формирование зрительского восприятия. Автореф... канд.искусствоведения. - М., 2007. - 25 c.

40. Винникова Т.А. Моделирование механизмов понимания кинотекста. Автореф... канд. филол.н. - Барнаул, $2010 .-26$ с.

41. Жабский М.И., Тарасов К.А. Развитие киноведения в институционально-контекстуальной перспективе // Культура и искусство.-2015.-1.-С. 16-31. DOI: 10.7256/2222-1956.2015.1.13481.

42. Лапин И.П. Как бы психология. Репортажи как документальное кино: Эссе. - СПб.: «Welcome», 2012.-159 c.

43. Михеева Ю.В. Игра в игре: музыкальные стилизации в кинематографе // Философия и культура. - 2014. - 11. - С. 1684 - 1689. DOI: 10.7256/1999-2793.2014.11.10617.

44. Сидорова Г.П., Шутая Н.К. «Мужской» характер и «женское» творчество кинорежиссеров-женщин // Культура и искусство. - 2015. - 5. - С. 511 - 519. DOI: 10.7256/2222-1956.2015.5.15822. 


\section{Психотехника}

45. Гуревич П.С. «Что не подвластно мне?» (Опыт эмоциональной раскадровки) // Филология: научные исследования. 2015. - 4. - C. 288 - 291. DOI: 10.7256/2305-6177.2015.4.17487.

46. Миркина 3.А. Кинематограф потаённой сердечной глубины (рецензия) // Филология: научные исследования. 2015. - 3. - C. 275 - 278. DOI: 10.7256/2305-6177.2015.3.16984.

47. Слышкин Г.Г., Ефремова М.А. Кинотекст: Опыт лингвокультурологического анализа. - М.: «Водолей Publishers», 2004. - 153 с.

48. Хренов Н.А. Проект семиотики кино спустя несколько десятилетий: интерпретация теоретического наследия С. М. Эйзенштейна Вяч. Вс. Ивановым // Культура и искусство.-2014.-6.-С. 634-652. DOI: 10.7256/2222-1956.2014.6.13239.

49. Дудник Д.В. Жанровая психодиагностика в кинотерапии // Практическая психология 2004. Т. 7. - Екатеринбург: Издательство УрГПУ, 2004. - С. 99-108.

50. Дудник Д.В. Кинотерапия-методология и техника // Практическая психология 2004. Т. 7. Екатеринбург: Издательство УрГПУ, 2004. - С. 86-99.

51. Дудник Д.В., Ворошилин С. И., Трифонов Б. А. Лечение депрессивных расстройств методом видеоарттерапии у военнослужащих Уральского округа ВВ МВД РФ // Тюменский медицинский журнал. - 2007, № 1. - С. 11-12.

52. Дудник Д.В., Ворошилин С. И., Трифонов Б. А. Новый метод психотерапии-«психоаналитическая видеоарттерапия» и лечение психогенных психических расстройств у военнослужащих срочной службы // Уральский медицинский журнал. Тематический сборник «Психиатрия»-2007, № 4. - С. 21-26.

53. Дудник Д.В., Требухов С.Н. Жанр кинобоевика как стимульный материал для работы в психотерапевтических группах с дезадаптированными военнослужащими // Гуманитарное знание и образование в контексте модернизации России. Материалы научной конференции. - Екатеринбург: Изд-во Уральского гуманитарного института, 2001. С. 297-301.

54. Дудник Д.В., Трифонов Б.А. Использование кинотерапии в лечении пограничных психических расстройств // Материалы 36-й областной научно-практической конференции врачей Курганской области.-Курган: Издательство «ДЕКА», 2004. - С. 161-163.

55. Кинотерапия. Рабочая программа дисциплины / Сост. С. В. Березин.-Самара: Самарский ун-т, $2001 .-7$ с.

56. Бурно М. Е. Терапия творческим самовыражением: Учебное пособие по психотерапии. 3-е изд., испр. и доп. - М.: «Академический Проект», 2006. -429 с.

57. Менегетти А. Мир образов: Краткое пособие по интерпретации образов и сновидений. Изд. 5-е, испр. и доп. - М.: Научн.фонд «Антонио Менегетти», 2015.-191 с.

58. Сергеева 0. Б. Эстетика Антонио Менегетти. Автореф... канд. филос. н.-Екатеринбург, 2011.-21 с.

59. Морено Я. Л. Психодрама / Пер. с англ. Г. Пимочкиной, Е. Рачковой. 2-е изд., испр. - М.: «Психотерапия», 2008. - 492 с.

60. Перлз Ф. С. Гештальт-семинары. - М.: Ин-т общегуманитарных исслед., 2010. - 348 с.

61. Перлз Ф. С. Гештальтподход и свидетель терапии / Пер. с нем. М. Папуша. - М.: «Гаудеамус»; «Академический проект», 2015. - 206 c.

62. Эриксон М. Семинар с доктором медицины Милтоном Г. Эриксоном / Ред. и коммент. Джеффри К. Зейга; пер. с англ. Т. К. Кругловой.-М.: «Класс», 2003.-334 с.

63. Эриксон М., Росси Э., Росси Ш. Гипнотические реальности: Наведение клинического гипноза и формы косвенного внушения / Пер. с англ. М. А.Якушиной под ред. М. Р. Гинзбурга. - М.: «Класс», 2007. - 348 с.

64. Бэндлер Р., Гриндер Дж., Делозье Дж. Полный курс гипноза. Паттерны гипнотических техник Милтона Эриксона. М.: АСТ «Прайм», 2015. - 501 с.

65. Гордон Д., Майерс-Андерсон М. Феникс: Терапевтические паттерны М. Эриксона / Пер. с англ. Н. Миронов. 2-е междунар. изд.-СПб.: Прайм-Еврознак; М.: ОЛМА-Пресс, 2004. - 187 с.

66. Дилтс Р. Убеждения и привычки. Как изменить? / Пер. с англ. А. Стативка. 2-е изд.-Москва: «Питер», $2013 .-219$ с.

67. Штайнер Р. Теория и практика медитации / Пер. с нем. С. Шнитцера.-Ереван: «Лонгин», 2009. - 174 с.

68. Штайнер Р. Художественная речь и драматическое искусство / Пер. с нем. Е. Н. Красоткиной .-М.: «Новалис», 2013.$525 \mathrm{c}$.

69. Штайнер Р., Вегман И. Основы развития врачебного искусства согласно исследованиям духовной науки / Пер. с нем. Андрея Локтева.-СПб.: «Деметра», 2008. - 122 с.

70. Сергеев А.А. Диагностика наркоаддикций, суицидального поведения и психоэмоциональных травм с помощью короткометражного авторского кино // Актуальные вопросы наркологии и психиатрии. Под ред. Акад. РАМН В.Я.Семке. Вып.15. Материалы 15 научной отчетной сессии НИИ психического здоровья СО РАМН (Томск, 6-7 сентября 2011 г.). - Томск, 2011. - С. 192-193.

71. Лазерная допплеровская флоуметрия микроциркуляции крови / Под редакцией А.И. Крупаткина, В.В. Сидорова. M., 2005. - 125 c.

72. Пантелеев С. С., Багаев В. А., Ноздрачев А. Д. Кортикальная модуляция висцеральных рефлексов.- СПб., 2004. - 208 c.

73. Золотухина Е.В. Личное прошлое как экзистенциальная проблема // Психолог. - 2012. - 2. - C. 34 - 76. URL: http:// www.e-notabene.ru/psp/article_144.html

74. Корнеенков С.С. Психодиагностика, психокоррекция и психотерапия субъективных переживаний страха в измененных состояниях сознания // Психолог. - 2013. - 4. - С. 238 - 278. DOI: 10.7256/2409-8701.2013.4.122. URL: http:// www.e-notabene.ru/psp/article_122.html

\section{References (transliterated):}

1. Apresyan Yu.D. Model' «Smysl-Tekst» na sovremennom etape: teoriya i prilozheniya // Fonetika i nefonetika. K 70-letiyu Sandro V. Kodzasova.-M.: «Yazyki slavyanskikh kul'tur», 2008.-S. 87-103. 


\section{Психология и психотехника 4(91) • 2016}

2. Apresyan Yu.D. Ot istiny do lzhi po prostranstvu yazyka // Logicheskii analiz yazyka. Mezhdu lozh'yu i fantaziei. Otv. red. chlen-korrespondent RAN N.D. Arutyunova.-M., 2008.-S. 23-45.

3. Apresyan Yu.D., Apresyan V.Yu., Babaeva E.E., Boguslavskaya O.Yu., Iomdin B.L., Krylova T.V., Levontina I.B., Sannikov A.V., Uryson E.V. Yazykovaya kartina mira i sistemnaya leksikografiya.-M.: Shkola «Yazyki slavyanskikh kul'tur», $2006 .-910 \mathrm{~s}$.

4. Vezhbitskaya A. Ponimanie kul'tur cherez posredstvo klyuchevykh slov / Per. s angl. A. D. Shmeleva. - M.: «Yazyki slavyanskoi kul'tury», 2001. - $288 \mathrm{~s}$.

5. Vezhbitskaya A. Yazyk. Kul'tura. Poznanie / Per. s angl., otv. red. M. A. Krongauz, vstup. st. E. V. Paduchevoi. - M.: «Pusskie slovari», 1996. - $416 \mathrm{~s}$.

6. Levontina I. B., Shmelev A. D., Zaliznyak A. A. Konstanty i peremennye russkoi yazykovoi kartiny mira.- M.: «Yazyki slavyanskoi kul'tury», 2012.- 696 c. (Yazyk. Semiotika. Kul'tura) .

7. Uryson E.V. Problemy issledovaniya yazykovoi kartiny mira: Analogiya v semantike.-M.: «Yazyki slavyanskoi kul'tury», 2003. - $224 \mathrm{~s}$.

8. Pavlovich N. V.Yazyk obrazov: paradigmy obrazov v russkom poeticheskom yazyke. 2-e izd., ispr. i dop. - M.: «Azbukovnik», 2004. $-528 \mathrm{~s}$

9. Moreno Ya. L. Sotsiometriya: Eksperimental'nyi metod i nauka ob obshchestve / Per. s angl. A. Bokovikova.-M.: «Akadem. Proekt», 2004.-315 s.

10. Perlz F. S. Teoriya geshtal't-terapii = Gestalt therapy: excitement and growth in the human personality / Per. s angl. A. Kornevoi, V. Petrenko. - M.: In-t obshchegumanitarnykh issledovanii, 2008. - $318 \mathrm{~s}$.

11. Burno M. E. Klinicheskii teatr-soobshchestvo v psikhiatrii. - M.: «Al'ma Mater»; «Akad. Proekt», $2009 .-718 \mathrm{~s}$.

12. Burno M. E. Klinicheskaya psikhoterapiya: Uchebnoe posobie po psikhoterapii. 2-e izd., pererab. i dop. - M.: «Akademicheskii Proekt»; Ekaterinburg: «Delovaya kniga», 2006. - 719 s.

13. Leitts G. Psikhodrama: Teoriya i praktika. Klassicheskaya psikhodrama Ya. L.Moreno / Per. s nem. A. M. Bokovikova. Izd. 2-e, ispr. i dop. - M.: «Kogito-Tsentr», 2007.-379 s.

14. Menegetti A. Obraz i bessoznatel'noe. [Izd. 2-e.pererab. i dop. - M.: «0ntopsikhologiya», 2009.-604 s.

15. Menegetti A. Vvedenie v ontopsikhologiyu. Izd. 2-e, ispr. i dop. - M.: «Ontopsikhologiya», 2006. - $127 \mathrm{~s}$.

16. Menegetti A. Sistema i lichnost'. Izd. 4-e, ispr. i dop. - M.: Nauch. fond «Antonio Menegetti», 2015.-276 s.

17. Erikson M. Gipnoterapiya: Sluchai iz praktiki / Per. s angl. pod obshch. red. G.Butenko. - M.: «Psikhoterapiya», $2013 .-516$ s.

18. Erikson M. Strategiya psikhoterapii = Strategy of the Psychotherapy: Izbrannye raboty / Avtorizov. per. s angl. i red. Shlionskii L.M.-SPb.: «Rech'», 2002. - 542 s.

19. Korneenkov S.S. Psikhodiagnostika, psikhokorrektsiya i psikhoterapiya sub"ektivnykh perezhivanii strakha v izmenennykh sostoyaniyakh soznaniya // Psikholog. - 2013. - 4. - C. 238 - 278. DOI: 10.7256/2409-8701.2013.4.122. URL: http://www.enotabene.ru/psp/article_122.html

20. Lotman Yu.M. Semiotika kino i problemy kinoestetiki. - Tallin: Izdatel’stvo «Eesti Raamat», 1973. - 137 s.

21. Lotman Yu.M., Tsiv'yan Yu.G. Dialog s ekranom.-Tallinn: «Aleksandra», 1994.-215 s.

22. Faryno E. Vvedenie v literaturovedenie.-M.: Izdatel'stvo RGPU im. A.I. Gertsena, 2004. - 639 s.

23. Petrenko V.F. Osnovy psikhosemantiki.-2-e izd., dop. - SPb.: «Piter», 2005. - $480 \mathrm{~s}$.

24. Krokinskaya O.K., Possel' Yu.A., Sikevich Z.V. Sotsial'noe bessoznatel'noe. - SPb.: «Piter», 2005.-272 s.

25. Uznadze D.N. Psikhologiya ustanovki.-SPb.: «Piter», 2001. - 416s.

26. Luriya A. R. Yazyk i soznanie / Pod redaktsiei E. D. Khomskoi. -- M: Izd-vo Mosk. un-ta, 1979.-320 s.

27. Kostandov E.A. Psikhofiziologiya soznaniya i bessoznatel'nogo.-SPb., 2004. - $176 \mathrm{s.}$

28. Menegetti A. Mudrets i iskusstvo zhizni. Izd. 4-e .-M.: Nauch. fond «Antonio Menegetti», 2015.-113 s.

29. Menegetti A. Kino, teatr, bessoznatel'noe. T. 1. / Per.s ital.: Rodik M. A. i dr. 2. izd., ispr. i dop.-M.: «0ntopsikhologiya», 2004. 264 s.

30. Menegetti A. Kino, teatr, bessoznatel'noe. T.2. / Per.s ital.: Rodik M. A. i dr.-2. izd., ispr. i dop.-M.: «Ontopsikhologiya», 2003. $222 \mathrm{~s}$.

31. Sukharebskii L. M. Voenno-sanitarnye meditsinskie i fizkul'turnye kinofil'my. 2-e izd. - M.: «Glavkinoprokat», $1944 .--26 \mathrm{~s}$.

32. Lavrent'ev V.I. Meditsinskii uchebnyi fil'm-vozmozhnosti, stsenarii, ispol'zovanie // Materialy Vsesoyuz. nauch.-metod. konferentsii po optimizatsii ucheb. protsessa v vyssh. med. ucheb. zavedeniyakh.-Kaunas, 1969.-24 s.

33. Burno M. E. Terapiya tvorcheskim samovyrazheniem: Otechestvennyi klinicheskii psikhoterapevticheskii metod. Uchebnoprakticheskoe posobie po psikhoterapii i psikhologicheskomu konsul'tirovaniyu. 4-e izd., ispr. i dop. - M.: «Al'ma Mater»; «Akademicheskii Proekt», 2012.-487 s.

34. Zolotovitskii R. A. Organizatsionnaya artterapiya i trening = Organizational arttberapy: Sotsiodrama i sotsiometriya v rabote s organizatsiei.-M.: «Moreno-Institut»; ARK «Biznes Grupp», 2003.-208 s.

35. Mastronardi V.M. I film che aiutano a stare meglio: Filmtherapy.-Roma: «Armando», 2010.-237 s.

36. Vasyutin A. M. Psikhoanimatsionnaya terapiya, ili Lechenie boleznei dushi i tela s pomoshch'yu obraznykh psikhoterapevticheskikh fil'mov.-Rostov-na-Donu: «Feniks», 2015. - 316 s.

37. Dudnik D.V. Situatsionno obuslovlennye psikhogennye psikhicheskie rasstroistva u voennosluzhashchikh vnutrennikh voisk Ministerstva vnutrennikh del Rossiiskoi Federatsii v usloviyakh voinskoi sluzhby vne boevykh deistvii i ikh lechenie. Avtoref... kand.med.n. - Orenburg, 2007. - 26 s.

38. Kashchuk A.A. Suggestivnye svoistva televideniya. Avtoref... kand.iskusstvovedeniya. - M., 2007. - 26 s.

39. Chikiris A.G. Televizionnoe veshchanie. Formirovanie zritel'skogo vospriyatiya. Avtoref... kand.iskusstvovedeniya. - M., 2007. - 25 s.

40. Vinnikova T.A. Modelirovanie mekhanizmov ponimaniya kinoteksta. Avtoref... kand. filol.n. - Barnaul, 2010. - 26 s.

41. Zhabskii M.I., Tarasov K.A. Razvitie kinovedeniya v institutsional'no-kontekstual'noi perspektive // Kul'tura i iskusstvo.2015.-1.-C. 16-31. DOI: 10.7256/2222-1956.2015.1.13481. 


\section{Психотехника}

42. Lapin I.P. Kak by psikhologiya. Reportazhi kak dokumental'noe kino: Esse. - SPb.: «Welcome», 2012.-159 s.

43. Mikheeva Yu.V. Igra v igre: muzykal'nye stilizatsii v kinematografe // Filosofiya i kul'tura. - 2014. - 11. - C. 1684 - 1689. DOI: 10.7256/1999-2793.2014.11.10617.

44. Sidorova G.P., Shutaya N.K. «Muzhskoi» kharakter i «zhenskoe» tvorchestvo kinorezhisserov-zhenshchin // Kul'tura i iskusstvo. - 2015. - 5. - C. 511 - 519. DOI: 10.7256/2222-1956.2015.5.15822.

45. Gurevich P.S. «Chto ne podvlastno mne?» (Opyt emotsional'noi raskadrovki) // Filologiya: nauchnye issledovaniya. - 2015. 4. - C. 288 - 291. DOI: 10.7256/2305-6177.2015.4.17487.

46. Mirkina Z.A. Kinematograf potaennoi serdechnoi glubiny (retsenziya) // Filologiya: nauchnye issledovaniya. - 2015. - 3. C. 275 - 278. DOI: 10.7256/2305-6177.2015.3.16984.

47. Slyshkin G.G., Efremova M.A. Kinotekst: Opyt lingvokul'turologicheskogo analiza. - M.: «Vodolei Publishers», 2004. - 153 s.

48. Khrenov N.A. Proekt semiotiki kino spustya neskol'ko desyatiletii: interpretatsiya teoreticheskogo naslediya S. M. Eizenshteina Vyach. Vs. Ivanovym // Kul'tura i iskusstvo.-2014.-6.-C. 634-652. DOI: 10.7256/2222-1956.2014.6.13239.

49. Dudnik D.V. Zhanrovaya psikhodiagnostika v kinoterapii // Prakticheskaya psikhologiya 2004. T. 7. - Ekaterinburg: Izdatel'stvo UrGPU, 2004. - S. 99-108.

50. Dudnik D.V. Kinoterapiya-metodologiya i tekhnika // Prakticheskaya psikhologiya 2004. T. 7. Ekaterinburg: Izdatel'stvo UrGPU, 2004. - S. 86-99

51. Dudnik D.V., Voroshilin S. I., Trifonov B. A. Lechenie depressivnykh rasstroistv metodom videoartterapii u voennosluzhashchikh Ural'skogo okruga VV MVD RF // Tyumenskii meditsinskii zhurnal. - 2007, № 1. - S. 11-12.

52. Dudnik D.V., Voroshilin S. I., Trifonov B. A. Novyi metod psikhoterapii-«psikhoanaliticheskaya videoartterapiya» i lechenie psikhogennykh psikhicheskikh rasstroistv u voennosluzhashchikh srochnoi sluzhby // Ural'skii meditsinskii zhurnal. Tematicheskii sbornik «Psikhiatriya»-2007, № 4. - S. 21-26.

53. Dudnik D.V., Trebukhov S.N. Zhanr kinoboevika kak stimul'nyi material dlya raboty v psikhoterapevticheskikh gruppakh s dezadaptirovannymi voennosluzhashchimi // Gumanitarnoe znanie i obrazovanie v kontekste modernizatsii Rossii. Materialy nauchnoi konferentsii. - Ekaterinburg: Izd-vo Ural'skogo gumanitarnogo instituta, 2001. - S. 297-301.

54. Dudnik D.V., Trifonov B.A. Ispol'zovanie kinoterapii v lechenii pogranichnykh psikhicheskikh rasstroistv // Materialy 36-i oblastnoi nauchno-prakticheskoi konferentsii vrachei Kurganskoi oblasti.-Kurgan: Izdatel'stvo «DEKA», 2004. - S. 161-163.

55. Kinoterapiya. Rabochaya programma distsipliny / Sost. S. V. Berezin.-Samara: Samarskii un-t, 2001.-7 s.

56. Burno M. E. Terapiya tvorcheskim samovyrazheniem: Uchebnoe posobie po psikhoterapii. 3-e izd., ispr. i dop. - M.: «Akademicheskii Proekt», 2006. - 429 s.

57. Menegetti A. Mir obrazov: Kratkoe posobie po interpretatsii obrazov i snovidenii. Izd. 5-e, ispr. i dop. - M.: Nauchn.fond «Antonio Menegetti», 2015.-191 s.

58. Sergeeva 0. B. Estetika Antonio Menegetti. Avtoref... kand. filos. n.-Ekaterinburg, 2011.-21 s.

59. Moreno Ya. L. Psikhodrama / Per. s angl. G. Pimochkinoi, E. Rachkovoi. 2-e izd., ispr. - M.: «Psikhoterapiya», 2008. - 492 s.

60. Perlz F. S. Geshtal't-seminary. - M.: In-t obshchegumanitarnykh issled., 2010. - $348 \mathrm{~s}$.

61. Perlz F. S. Geshtal'tpodkhod i svidetel' terapii / Per. s nem. M. Papusha. - M.: «Gaudeamus»; «Akademicheskii proekt», 2015. $206 \mathrm{~s}$.

62. Erikson M. Seminar s doktorom meditsiny Miltonom G. Eriksonom / Red. i komment. Dzheffri K. Zeiga; per. s angl. T. K. Kruglovoi.-M.: «Klass», 2003.-334 s.

63. Erikson M., Rossi E., Rossi Sh. Gipnoticheskie real'nosti: Navedenie klinicheskogo gipnoza i formy kosvennogo vnusheniya / Per. s angl. M. A.Yakushinoi pod red. M. R. Ginzburga. - M.: «Klass», 2007. - 348 s.

64. Bendler R., Grinder Dzh., Deloz'e Dzh. Polnyi kurs gipnoza. Patterny gipnoticheskikh tekhnik Miltona Eriksona. - M.: AST «Praim», 2015. - $501 \mathrm{~s}$

65. Gordon D., Maiers-Anderson M. Feniks: Terapevticheskie patterny M. Eriksona / Per. s angl. N. Mironov. 2-e mezhdunar. izd.SPb.: Praim-Evroznak; M.: OLMA-Press, 2004. - 187 s.

66. Dilts R. Ubezhdeniya i privychki. Kak izmenit’? / Per. s angl. A. Stativka. 2-e izd.-Moskva: «Piter», 2013.-219 s.

67. Shtainer R. Teoriya i praktika meditatsii / Per. s nem. S. Shnittsera.-Erevan: «Longin», 2009. - $174 \mathrm{~s}$.

68. Shtainer R. Khudozhestvennaya rech' i dramaticheskoe iskusstvo / Per. s nem. E. N. Krasotkinoi .-M.: «Novalis», $2013 .-525$ s.

69. Shtainer R., Vegman I. Osnovy razvitiya vrachebnogo iskusstva soglasno issledovaniyam dukhovnoi nauki / Per. s nem. Andreya Lokteva.-SPb.: «Demetra», 2008. - $122 \mathrm{~s}$.

70. Sergeev A.A. Diagnostika narkoaddiktsii, suitsidal'nogo povedeniya i psikhoemotsional'nykh travm s pomoshch'yu korotkometrazhnogo avtorskogo kino // Aktual'nye voprosy narkologii i psikhiatrii. Pod red. Akad. RAMN V.Ya.Semke. Vyp.15. Materialy 15 nauchnoi otchetnoi sessii NII psikhicheskogo zdorov'ya SO RAMN (Tomsk, 6-7 sentyabrya 2011 g.). Tomsk, 2011. - S. 192-193.

71. Lazernaya dopplerovskaya floumetriya mikrotsirkulyatsii krovi / Pod redaktsiei A.I. Krupatkina, V.V. Sidorova. - M., 2005. $125 \mathrm{~s}$.

72. Panteleev S. S., Bagaev V. A., Nozdrachev A. D. Kortikal'naya modulyatsiya vistseral'nykh refleksov.- SPb., 2004. - 208 s.

73. Zolotukhina E.V. Lichnoe proshloe kak ekzistentsial'naya problema // Psikholog. - 2012. - 2. - C. 34 - 76. URL: http://www.enotabene.ru/psp/article_144.html

74. Korneenkov S.S. Psikhodiagnostika, psikhokorrektsiya i psikhoterapiya sub"ektivnykh perezhivanii strakha v izmenennykh sostoyaniyakh soznaniya // Psikholog. - 2013. - 4. - C. 238 - 278. DOI: 10.7256/2409-8701.2013.4.122. URL: http://www.enotabene.ru/psp/article_122.html 